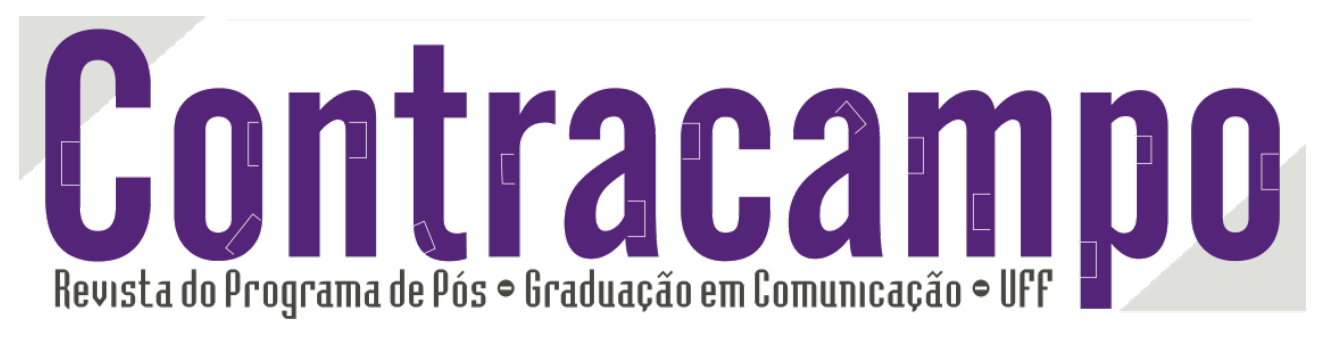

\title{
A Retórica que Veio do Espaço: Imaginação sentimental, razão oculta e fronteiras da ficção no cinema de horror contemporâneo
}

\author{
The Rhetoric that Came from Space:
}

Sentimental imagination, hidden reason and boundaries of fiction in contemporary horror cinema

Klaus Berg Nippes Bragança klausbraganca@ymail.com Graduado em Comunicação Social UFES. Mestre em Comunicação e Cultura Contemporâneas pelo PósCom/UFBA. Doutorando do PPGCOM/UFF. Professor assistente substituto do departamento de Cinema e Vídeo do IACS/UFF.

' Uma versão deste artigo foi aceita para apresentação no $16^{\circ}$ Encontro da Socine realizado entre 08 e 11 de outubro de 2012 no Zentro Universitário Senac de São Paulo.

\section{PPGCOM}

Ao citar este artigo, utilize a seguinte referência bibliográfica

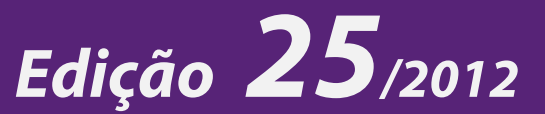

Ensaio temático "Mídia e Medo"

SOBRENOME, Nome dos autores. Título do trabalho. In: Revista Contracampo, n‥25, dez de 2012. Niterói: Contracampo, 2012. Pags: 61-79.

\section{Contracampo}

Niterói $(R J), n^{\circ} 25$, ed. dez/2012. 


\section{Resumo}

Este trabalho investiga filmes de horror que amparam suas narrativas em modos de condução estética e historicamente realistas para respaldar proposições ficcionais excessivas. Toma-se como objeto deste problema filmes recentes que tematizam os mistérios dos mundos extraterrenos, como Contatos de $4^{\circ} \mathrm{Grau}$ (2009) e Apollo 18 (2011). Partindo do pressuposto de que as obras convocam uma atmosfera de dúvida sobre o senso comum do receptor, debate-se a questão dos afetos condicionados pela retórica da imaginação e pelo engajamento sensorial.

Palavras-chave: Horror, Realismo, Desconhecido.

\section{Abstract}

This work investigates horror films that sustain their narratives in aesthetic and historically realistic driving modes to support the excessive fictional propositions. As object were chosen recent films that fable the mysteries of the worlds from outer space, as The Fourth Kind (2009) and Apollo 18 (2011). On the assumption that the films draw an atmosphere of doubt over the viewer common sense, we debate the question about the conditioned affections by the rhetoric of imagination and the sensorial engagement.

Keywords: Horror; Realism; Unknow. 
Os mundos do horror

Ariosto me enseñó que en la dudosa luna moran los sueños, lo inasible, el tiempo que se pierde, lo posible o lo imposible, que es la misma cosa.

Jorge Luis Borges, La Luna.

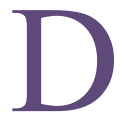

esde muito cedo o cinema revelou um potencial ilusório capaz de obscurecer as fronteiras entre a realidade e a imaginação - basta recordar da lendária exibição dos irmãos Lumière ao projetar a chegada de um trem à estação (L'Arrivée dun train à la Ciotat, 1896) - a atração, o arrepio e a incompreensão do público em relação à fantasmagórica locomotiva demonstrava como a inovadora tecnologia do final do século XIX poderia coagir nossa percepção a tomar a reprodução imagética como uma realidade aterrorizante. Valendo-se desse potencial, os temas sombrios e sobrenaturais remontam ao início da formação da linguagem, desde o Primeiro Cinema com as ilusões e assombrações de Georges Méliès, até as vanguardas europeias da década de 1920, consagrados principalmente na "atmosfera de pesadelo" do Expressionismo alemão.

O cinema de horror parece acompanhar as reordenações da sociedade, adaptando-se às diferentes oscilações de pensamento derivadas dos embates e conflitos que atravessam a história do século XX (POLAN, 1997). Depois da Segunda Guerra (e do sucesso dos filmes de monstros dos estúdios Universal na década de 1930), Hollywood estabeleceu ciclos de horror que passaram a esboçar ou mesmo posicionar as angústias e medos da sociedade, pois "se, no passado, o medo vinha sobretudo da natureza e do sobrenatural, hoje o principal perigo vem do próprio homem e das incertezas produzidas pela tecnociência" (NOVAES, 2007: 11). Desta forma os horrores científicos da mobilização atômica esboçada pela Guerra Fria na década de 1950 deram vazão a filmes que mostravam criaturas deformadas e gigantescas originadas da má utilização da tecnociência pelo homem: um regime de visualização das monstruosidades que a perversidade humana poderia produzir.

Com o aprimoramento das tecnologias de registro fotográfico e audiovisual a Guerra do Vietnã foi provavelmente o primeiro conflito armado que recebeu ampla cobertura midiática, apresentando dores, feridas e mortes de um modo explícito e repugnante. Este elemento visceral foi apropriado pelo cinema logo nas décadas de 1960 e 1970 e se tornou a marca estética característica de filmes sanguinolentos, psicóticos e chocantes que ressaltavam explicitamente as brutalidades do horror. Várias classificações foram surgindo para integrar este universo como 
gore $^{1}$ ou até mesmo trash e Filme $B^{2}$, aludindo aos defeitos técnicos e às cenografias pobres que as produções exibiam.

Ícones monstruosos nascidos com o gore ganharam fama impulsionando a produção de franquias de assassinos seriais e esquartejadores de adolescentes promíscuos. Tais modelos, chamados de slashers, reanimaram a produção dos filmes de horror nas décadas de 1980 e de 1990 através de matadores que empunhavam armas cortantes para dilacerar várias pessoas ao longo de suas narrativas. Estes filmes espelhavam a insegurança da vida urbana, fadada a ser acometida pela violência cotidiana a qualquer tempo e lugar. $O$ constante estado de alerta para a insegurança nas cidades se intensificou após os atentados de 11 de setembro, pois demonstrava os perigos imprevisíveis que o Outro poderia causar em um ambiente doméstico.

A resposta ocidental ao inimigo terrorista foi denunciada pela imprensa, destacando a violência usada pelo exército norte-americano em suas táticas de interrogatório e tortura justificadas como consequência do combate ao terror. Imagens que chocavam por mostrar a crueldade e a humilhação que um ser humano poderia submeter a outro. Interagindo com esta realidade paranoica e opressora o cinema de horror da primeira década do século XXI apresentou narrativas dedicadas a mostrar explicitamente torturas repulsivas de homens e mulheres impotentes contra esta violência. Propunham um espetáculo obsceno de sadismo, dor e morte sintomaticamente chamado de torture porn ${ }^{3}$.

Cada época possui uma fatia de filmes de horror que parece expressar ou enfatizar suas próprias crises e fobias. $\mathrm{E}$ se em todos os ciclos mencionados os horrores tendem a espelhar ameaças produzidas pela humanidade e vindas da humanidade, nos últimos anos alguns filmes deram o lugar das ameaças terrenas para perigos mais incríveis e supersticiosos, recorrendo a temas aproximados à origem do gênero, na qual as certezas do senso comum são confrontadas pelas dúvidas da imaginação. Esta retomada do ocultismo parece mostrar, como diz Adauto Novaes, que "velhos medos - teológicos e metafísicos -, que guardam ainda algum prestígio, são feitos no silêncio da imaginação. Eles nos convidam a pensar e agir com prudência porque, ainda que invisíveis, [...] são medos absolutos" (2007: 11).

Segundo Riegler (2009: 115) essa tendência ancora-se nos tempos de incerteza plena, épocas de desconfiança sobre as instituições, autoridades e verdades universais, dúvidas que fazem ser "mais difícil do que nunca encontrar orientação, o que torna a religião e as mitologias

\footnotetext{
${ }^{1}$ Ver AUMONT; MARIE, 2006: 146, “o termo designou uma categoria marginal de filmes de horror de pequeno orçamento, cujo objetivo era provocar uma reação violenta de repulsão e de nojo no espectador". 2 "Série B" vocábulo catalogado em JOURNOT, 2005: 136-137, é interessante como definição para essas "pequenas produções de filmes de gênero de qualidade medíocre".

${ }^{3}$ Filmes de horror que submetem as vítimas a torturas, degradações e autoflagelações, bastante em voga no começo do século XXI com as franquias Jogos Mortais (2004) e O Albergue (2005).
} 
sobrenaturais atraentes para lidar com a realidade" ${ }^{4}$. De maneira semelhante, a fronteira do universo com nosso mundo sempre foi um motivo de atenção e especulação entre os seres humanos, cativando nossa curiosidade e criatividade em questionar o não-conhecimento absoluto que cerca nosso planeta.

O cinema também reconheceu essa potência imaginária ainda bem cedo: novamente com Méliès e sua viagem à lua até Kubrick e sua odisseia espacial, a condução pelos confins do universo estipulou parâmetros que fizeram nossa imaginação se debruçar sobre nossas pretensões. Ainda hoje este é um pano de fundo comum para gêneros distintos, como a ficção científica e o horror - cuja combinação foi canonizada principalmente pela franquia Alien, pregando que "no espaço ninguém pode te ouvir gritar".

As dúvidas calcadas na vastidão indefinida do universo atualizaram as tramas de horror e alguns filmes procuraram realçar essas incertezas através de estratégias retóricas que mobilizam a imaginação a conceder uma razão para os excessos ficcionais serem respaldados e validados como hipóteses possíveis. Filmes que constroem estratégias de visualidades embasadas em formatos mais aptos a condicionar afetos devido a um estatuto de veracidade, como o documentário, a tele-reportagem, o reality show e o vídeo amador. As narrativas tentam fomentar uma impressão de realismo para sustentar suas ficções.

Filmes como Contatos de $4^{\circ}$ Grau (The fourth Kind, 2009) e Apollo 18 (2011) corroboram seus relatos apoiando-se em estéticas fílmicas historicamente mais próximas a um modo realista de mostrar o mundo (BROOKS, 2005), como a câmera de vigilância, a reencenação, a entrevista e o documentário científico. Com estes formatos as ficções de horror realçam as incertezas sobre seus mistérios, edificando construções retóricas que mobilizam a imaginação a conceder uma lógica para respaldar os excessos e incrementar o resultado da experiência de horror, pois eles têm a particularidade de assumir um discurso de autenticidade e fidedignidade - estreitam os vínculos com às categorias discursivas de legitimidade testemunhal adquiridas sobretudo pela portabilidade que tais formatos capacitam.

Se Contatos de $4^{\circ}$ Grau tenta reforçar a credibilidade de sua hipótese sobre abdução extraterrestre através de uma montagem alternada entre cenas de entrevistas de um programa televisivo, com cenas de reconstituição dos eventos relatados e ainda com as imagens de arquivo do caso (algumas vezes agrupando todas por split screen em um mesmo plano); Apollo 18 contraria esta lógica forjada e procura conduzir seu testemunho sobre os mistérios ocultos no lado escuro de nosso único satélite natural de forma linear, quase burocrático e nãointervencionista, como se fosse o registro de um experimento científico lunar. Ambas

\footnotetext{
${ }^{4}$ Esta e as demais citações das obras estrangeiras relacionadas nas referências foram traduzidas pelo autor deste trabalho.
} 
estratégias adentram territórios importantes para catalisar o engajamento sensorial e a crença narrativa - disposições caras para estimular um dos efeitos específicos das ficções de horror: o medo do desconhecido.

Partindo do pressuposto de que estes filmes de horror se apoiam em referências imaginárias e reais para fundamentar suas experiências, estaremos entrando em um paradoxo, pois o gênero caracteriza-se por exceder a normalidade, a lógica ou a realidade, e o pressuposto afirma que estes filmes sustentam suas experiências através de coerências e referências realistas. Se o gênero de horror precisa de uma violação da normalidade para funcionar adequadamente, como uma lógica realista poderia reforçar os efeitos do excesso narrativo do horror? Qual é o efeito produzido por um respaldo realista ao obscurecer e extrapolar a zona fronteiriça entre estéticas mais artificiais e mais realistas? Quais são os procedimentos fílmicos usados para burlar esta fronteira?

\section{Uma imaginação sentimental do desconhecido?}

Não é possível dizer com precisão, mas a primeira vez que o ser humano olhou para os céus sua imaginação atravessou a barreira que a visão impunha a sua curiosidade. A curiosidade sobre o mundo e o que está acima dele fundamentaram teorias e religiões, crenças e dúvidas, verdades e ficções. Seja qual for a vertente, há sempre uma força da imaginação para condicionar afetos.

O cinema vagueia em torno de todas as possibilidades citadas, norteia uma série de discussões que regularmente exemplificam as conviç̧ões e hipóteses debatidas através de "fatos" cinematográficos. Por exemplo, um vídeo amador mostrando óvnis pairando sobre prédios ou a dissecação de um alienígena pelo exército americano não vai necessariamente convencer ou atestar a existência de vida extraterrena, mas pode ao menos suscitar uma dúvida sobre sua legitimidade, o que já demonstra que existe algum tipo de imaginação sentimental ou uma vontade de pressionar a superfície da realidade para excitar a imaginação.

$\mathrm{O}$ não-conhecimento oferecido pelo espaço, os astros e os confins do universo obedece uma razão hipotética, isto é, uma construção lógica articulada por hipóteses e especulações. As verdades científicas atestadas, pouco conhecidas pela pessoa comum, acabam se emaranhando com invenções fictícias e incríveis para colonizar uma lacuna de certezas com sensos hiperbólicos. Especulações oferecidas a um não-conhecimento que impedem a hierarquia de uma razão única, estrita a um saber que domina o real. Imaginar o que não-se-conhece significaria entrar no jogo do mistério? 
Um jogo interpretativo do que está oculto da lógica e que precisa ser descoberto para restituir-se uma razão adequada a suas circunstâncias. Como a curiosidade pode ser atraída a esse não-conhecimento? Como seu vazio consegue estimular um preenchimento? Se estamos lidando com algo que sempre se apresenta encoberto, aquilo que não possui sentido direto e explícito, como uma retórica do que "falta" poderia estimular a imaginação?

Alcir Pécora, professor e crítico de literatura, aborda a questão do mistério a partir de seus estudos sobre a retórica da teologia cristã defendida nos Sermões de Antonio Vieira - que buscava significados e razões para os sinais de Deus ocultos nos objetos mundanos. Para Pécora o mistério vai de encontro ao casual, " [...] ao que não encontra razão para as correspondências, ou ao imaginário, quer dizer, ao que fantasia razões sem fundamento de ser. Em termos positivos, é saber documentado no exame das circunstâncias em que se propõe uma escolha conveniente" (1996: 161). Documentar a razão e o valor do que está oculto, do que é o mistério acima do mundo, faz parte desta retórica.

Vale frisar que o conceito de mistério usado por Pécora é convocado a partir de seus estudos sobre teologia e literatura cristã, preconizando o mistério Divino, o mistério dos planos de Deus que poderia ser interpretado por pessoas aptas a captar os sinais ocultos nos objetos comuns. Estamos ampliando o sentido do termo para emprega-lo nos filmes debatidos, uma manobra conceitual aplicada propositalmente para adentrar um território inerente ao problema da imaginação sentimental do desconhecido: o abalo das certezas, um tipo de desconfiança do senso comum.

Pécora alude a um termo de Baltasar Gracián, escritor, teólogo e filósofo do século XVII, no qual destaca o gosto engenhoso em alcançar a verdade difícil fornecida pela forma misteriosa: a ponderação misteriosa é uma ponderação de dificuldade, "uma dificuldade entre a conexão dos extremos" (apud. PÉCORA, 1996: 164). Para o autor, na forma misteriosa deveria incluir-se não apenas uma propriedade altamente persuasiva, para cativar atenção e interesse sobre o enigma, mas também um prazer transcendental em atingir a descoberta, e um artifício dramático. Em outros termos, uma dramaticidade adequada ao desempenho de uma razão oculta, na qual objetos e situações comuns assinalam uma natureza transcendental ao serem decifrados. Quais são os procedimentos usados para ocultar os valores transcendentais de objetos e situações comuns?

A razão oculta aparece mediada por um sinal, uma manifestação que indica uma natureza outra para a coisa, mas sua nitidez não é total ou plena. As narrativas implicam procedimentos de expectativa sobre o mistério, deixam suspensos seus valores ocultos postergando a descoberta da natureza outra dos sinais para o futuro, onde o alcance de seus efeitos podem então coincidir com o ápice da trama. As tramas apontam que toda visualidade 
dada oferece mais do que permite ver, seja de forma metafórica ao incorporar propriedades distintas em objetos comuns; ou seja de forma metonímica ao encobrir o todo, permitindo apenas a manifestação de fragmentos informativos e visuais. Por um lado os sinais excitam nossos sentidos, e com eles a imaginação e a emoção. Por outro lado, a recorrência dos sinais acaba gerando uma autonomia, torna-os também sinais do próprio objeto comum, algo frutífero para a manutenção de suas funções misteriosas, pois desvia nossa atenção e preserva a revelação de suas propriedades ocultas para o final.

Se articularmos o conceito de razão oculta aos estudos de Peter Brooks dedicados à imaginação melodramática, podemos ver certa similaridade operativa. No livro (1995: 06) o autor afirma que a imaginação melodramática precisa ser orientada e guiada por uma moral oculta, uma virtude camuflada e incorporada à trama que faz de seu valor incógnito uma aventura e seu reconhecimento, a consciência moral, atinge o auge do drama. No gênero melodramático a moral oculta é como uma liga elástica que prende seus elementos, mesmo que eles possam se estender para outras direções momentaneamente. É o reconhecimento do conflito moral pelo olhar público que nos convoca a tomar partido para julgar as atitudes dramáticas das personagens e nos emocionar com essa consciência.

No caso de uma imaginação sentimental do desconhecido, o oculto faz parte do próprio jogo imaginativo, o desafio indissolúvel que nos aventura em uma tormenta cognitiva e sentimental. A razão oculta, nesse caso, é o leitmotiv que conduz a ação da imaginação sentimental sobre o desconhecido, é a força motriz que interpela os vazios da trama a serem completados em busca dos conhecimentos e fatos que faltam para "racionalizar a relação com o desconhecido" (RANCIÈRE, 2007: 60).

O horror dos filmes aqui discutidos é adquirido a pari-passu das razões ocultas na narrativa, o mistério proposto forma uma lacuna onde os conhecimentos do senso comum não cabem e, portanto, deve-se preenchê-la com elementos da imaginação para dali retirar um sentimento apenas: o medo do desconhecido. A descoberta do mistério Divino na teologia cristã é digna de prazer, alegria e comemoração, porém tanto na narrativa de Contatos de $4^{\circ} \mathrm{Grau}$ quanto (e principalmente) em Apollo 18 a descoberta da razão oculta culmina para nós em medo, e para as personagens em angústia, sofrimento e morte.

Observando a composição narrativa dos filmes percebe-se a atuação da razão oculta no cerne da trama, desempenhando um artifício que requer obscuridade sobre as causas que conectam suas partes, caso contrário os mistérios propostos seriam desfeitos. A razão oculta é o fio condutor das partes, é o elo de ligação dos personagens e o motivo pelo qual tentamos desvendar o mistério. Mais além, a razão oculta sustenta duas narrativas que mal apresentam 
seus monstros - cujas aparições tradicionalmente são a fonte de angústia e medo nas ficções de horror.

Em Apollo 18 os monstros são até enquadrados por alguns momentos, mas sempre camuflados e mimetizados como pedras - que é a textura de sua pele alienígena e também o motivo oficial da missão, pois entre os objetivos da missão estava o de coletar minerais lunares e os astronautas fariam isso se a nave russa abandonada no "lado escuro" da lua não deslocasse sua atenção. As pedras ora espalhadas, ora organizadas pelas naves e pelo solo lunar servem como sinal de uma presença capaz de manipular tais objetos. Sugerem haver uma força capaz de atuar sobre os minerais, os astronautas e os módulos lunares. Nesse caso as próprias pedras materializam essa presença, apresentando-se como um ser vivo encoberto por sua aparência de objeto inanimado.

Para Brooks (1995: 09) é no nível da metáfora que se estabelecem transações entre contextos, onde se colocam propriedades reconhecíveis em uma variedade de possibilidades para encobrir e expandir a moral oculta do melodrama. Considerando a razão oculta do mistério, como visto, a metáfora também pode ser usada para encobrir ou expandir o significado incógnito, porém talvez a grande virtude no caso dos dois filmes debatidos (e talvez também do gênero de horror em geral) é o potencial metafórico em nomear ou mesmo representar a entidade monstruosa, aquilo que é a substância principal do não-conhecimento, uma entidade sem forma definida, explícita ou reconhecível pelas classificações mundanas.

Representar deve ser entendido com ressalvas, pois esta entidade monstruosa, tal qual a razão oculta, não deve ser revelada por completo antes do auge do drama, ou sua potência persuasiva perderá o valor. Dessa maneira, o monstro obedece a forma misteriosa, desempenhado metafórica e metonimicamente, ele mantem sua identidade encoberta por sentidos e objetos escusos que servem para "[...] anunciar que, por vezes, parecendo claros ou transparentes, tais objetos são apenas véus, vestígios, e que algo oculto existe naquilo mesmo que se dá a ver" (PÉCORA, 1996: 159). Tal estratégia amplia as inferências sobre a natureza e periculosidade da ameaça monstruosa, reservando suas aparições derradeiras aos momentos de descoberta da razão oculta. Na qualidade de presença sem corpo, o monstro realça seu poder persuasivo por acompanhar as disposições afetivas estimuladas pela razão oculta.

Contatos de $4^{\circ} \mathrm{Grau}$ expõe essa potência de maneira bem clara: com as inúmeras metáforas feitas ao longo da narrativa indicando uma força alienígena que não pode ser nomeada ou proferida, apenas imaginada. Esta força parece apossar-se de objetos comuns, indicada através de corujas brancas, ruídos nas gravações de áudio, sombras distorcidas e a lua, elementos que constituem a entidade sem corpo, a presença monstruosa que não se permite ver. É de fato uma presença constante, radicada no interesse despertado pela razão oculta. 
Atinge o ponto da aparição monstruosa ser representada através das próprias vítimas, que corporificam a força alienígena destituídas de suas vontades e expõem as intenções maléficas do monstro. Deformam-se os corpos exageradamente para as personagens poderem assumir o lugar do monstro, até as próprias imagens de registro gravadas "originalmente" pela pesquisadora se deformam com diversas interferências eletrônicas, transmitindo apenas vestígios e esboços do que seria a ação monstruosa - esse é o nível metonímico da imagem, permitindo ver por entre os defeitos de resolução audiovisual apenas esboços e fragmentos da corporificação monstruosa.

As metáforas e metonímias são modos de sinalizar o monstro, cativar a imaginação a estipular respostas para o mistério, conceber parâmetros para a forma monstruosa e ainda manter a progressão reveladora da razão oculta. Um interesse realçado pelas zonas de indeterminação da imagem, estímulos que nos fazem projetar a imaginação e tentar ver mais do que é permitido ser mostrado pelos dispositivos de visualidades - formatos empenhados em transmitir testemunhos e provas.

\section{As fronteiras da ficção: documentação e visualidades realistas do horror}

Segundo Brooks (1995: 09) a imaginação melodramática precisa igualmente de documentação e visão, e deve estar preocupada em extrapolar de uma a outra, em outras palavras, deve mostrar o documento, registrar o ato de documentação em si. No problema que nos concerne, a formulação de documentos como possíveis provas é uma teia desta imaginação sentimental. Entende-se o "documento" a partir das noções traçadas por Georges DidiHuberman em Images Malgré Tout (2003) por seu caráter de arquivo, prova, testemunho e registro de uma experiência.

Os filmes aproveitam-se de cada uma destas vertentes para absorver seus predicados verídicos e incorporar o valor de autenticidade que reforça a atuação de suas ficções. A listagem de documentos correlaciona as ficções às suas fontes documentais, sejam através de imagens de arquivo, furos testemunhais ou depoimentos daqueles que registraram suas experiências, como um processo de verificação de vestígios e evidências que configuram seus argumentos. Uma transmissão de conhecimento que é adquirida tanto em nível cognitivo bem como em nível sensacional, em uma relação "entre o que eu vejo aqui e o que eu sei de outro lugar" (DIDIHUBERMAN, 2003: 142).

De modo explícito os dois exemplares se posicionam como frutos de um trabalho árduo de documentação, incluindo ainda a quantidade de horas de material bruto gravado: antes dos créditos iniciais de Contatos de $4^{\circ} \mathrm{Grau}$, a atriz Milla Jovovich é convocada a se apresentar 
como a protagonista e alertar o espectador de que a narrativa é uma dramatização baseada em pesquisas verídicas do diretor Olatunde Osunsanmi que usou as gravações de áudio e vídeo das evidências originais coletadas pela Dra. Abigail Tyler, a personagem interpretada por Jovovich ${ }^{5}$, para apoiar as reencenações dramatizadas.

Embora a documentação erguida em Contatos de $4^{\circ}$ Grau com entrevistas e imagens de arquivo funcione como evidências de um mistério, o caso de Apollo 18 é diferente e singular, pois a obra extrapola a documentação apresentada pelo filme em outras vias, como a internet. Assim como o caso acima, o filme também anuncia sua legitimidade de documentação, mostrando um texto rápido sobre as missões anteriores à Apollo 18 para em seguida dizer que o filme foi editado a partir das imagens disponibilizadas no site lunartruth.com, apresentado como a fonte de toda a documentação do filme ${ }^{6}$. Um dossiê textual, fotográfico e audiovisual que sustenta a hipótese pregada pela película sobre vida alienígena no lado escuro da lua, além de fomentar outras hipóteses conspiratórias para estimular um processo empático que magnifica as razões expostas na narrativa.

O site é um depositório de documentos supostamente secretos que atestam as versões do filme, provas que foram "vazadas" por pessoas comuns mobilizadas em divulgar e tentar solucionar esses fatos exacerbados ${ }^{7}$. Sempre houveram comunidades de interessados sobre tais mistérios, ao passo que a arte estimulava cada vez mais um repertório em torno das dúvidas extraterrenas. Toda uma rede intertextual circula referenciando-se quase sempre em apelos hiperbólicos e inventivos: imagens e textos conspiratórios em fanzines, histórias em quadrinhos, literatura geek, blogs, discos, vídeos, séries e filmes. Apollo 18 apoia-se em um imaginário alastrado através de mistérios e razões ocultas sobre o espaço, aproveita a circulação de uma

\footnotetext{
${ }^{5}$ A fala inicial da atriz é a seguinte (grifos meus): "I'm actress Milla Jovovich, and I will be portraying Dr. Abigail Tyler in The Fourth Kind. This film is a dramatization of events that occurred October 1st through the 9th of 2000, in the Northern Alaskan town of Nome. To better explain the events of this story, the director has included actual archived footage throughout the film. This footage was acquired from Nome psychologist Dr. Abigail Tyler, who has personally documented over 65 hours of video and audio materials during the time of the incidents. To better protect their privacy, we have changed the names and professions of many of the people involved. Every dramatized scene in this movie is supported by either archived audio, video or as it was related by Dr. Tyler during extensive interviews with the director. In the end, what you believe is yours to decide. Please be advised, that some of what you're about to see is extremely disturbing".

${ }^{6} \mathrm{O}$ texto de abertura é o seguinte (grifos meus): "July 20, 1969 - Apollo 11 astronaut Neil Armstrong is the first man to walk on the moon. In 1970, Apollo missions 18, 19, and 20 were canceled due to budgetary concerns. December 7, 1972 - Apollo 17, the final official lunar mission, lands on the moon. In 2011, eighty-four hours of classified footage is uploaded to www.lunartruth.com. This film was edited from that footage".

${ }_{7}$ O próprio site lunartruth.com foi "alvo" de suposições exageradas, pois seu acesso era dificultado por uma interface escura ofuscando um link escondido que permitia a navegação pela página. Tão logo o artifício foi popularizado o site foi retirado do domínio original e passou a vagar por domínios com nomes parecidos, como lunatruth, moontruth e correlatos - é uma manobra para proteger sua versão das supostas autoridades que preferem encobri-la e ao mesmo tempo uma estratégia de divulgação alternativa coerente com a proposta subversiva do enredo.
} 
malha preexistente sobre os segredos das missões lunares para fecundar a imaginação e proteger sua trama.

Esta teia é tecida por uma diversidade de dados, registros e exemplos obtidos nas narrativas fílmicas e nos textos que dialogam com a racionalização correlacionada, forma uma malha densa de arquivos sistematicamente documentados. Podemos entender esse fetiche pela listagem de arquivos como uma retórica do excesso: uma luta entre coerência e contradição em que cada elemento pode atrair ou distrair nossa atenção sobre a narrativa. Tal estratégia, segundo Kristin Thompson (2004: 514), "surge do conflito entre a materialidade de um filme e suas estruturas unificantes".

Em seu artigo, a autora critica a assunção formalista de que composições realistas e motivações claras tendem a deixar os elementos excessivos menos notáveis, dado que o excesso implica uma falta de motivação. Para Thompson (2004: 517-518) existem modos do próprio excesso do material fílmico superar a noção de motivação: sejam os pontos de vista da câmera sobre um determinado elemento, a duração temporal desse elemento enquadrado em cena, a redundância de pontos de vista sobre o elemento, a repetição exagerada do elemento etc. O que se sobressai para o nosso problema é a redundância e a repetição que os elementos da narrativa podem sofrer em função de seu excesso.

Convém às obras analisadas principalmente por um dos aspectos de excesso fílmico que melhor caracteriza a materialização de uma razão oculta nas tramas: a ênfase na documentação narrativa, a profunda reiteração de arquivos, dados e informações que conformam as razões ocultas da ficção em fatos empíricos. A reiteração de elementos e documentos possui o potencial de dar coerência à trama, sustentar os sentidos metafóricos que detalham os sinais ocultos em objetos e elementos narrativos. Tal aspecto organiza as propostas ficcionais com uma lógica descritiva. A descrição dos fatos e do mundo narrativo contribui paradoxalmente nesse caso para fornecer apelos realistas aos excessos do horror.

Em seu livro dedicado ao realismo literário, Peter Brooks confere muita importância à minúcia descritiva, já que "a necessidade de incluir e de representar as coisas irá consequentemente implicar uma inspeção visual do mundo do fenômeno e um relatório detalhado dele - frequentemente um relatório na forma do que chamamos de descrição" (2005: 16). Dessa maneira a descrição funciona para o romance melodramático como um pilar da representação realista dos elementos ficcionais. Se deslocarmos a noção de descrição de Peter Brooks para a problemática do excesso narrativo no horror, a descrição realista funcionaria simultaneamente para respaldar e enfatizar tal excesso.

Nos filmes que se apropriam de formas misteriosas, os objetos registrados repetitivamente são mais prováveis de se tornarem excessivos, especialmente se receberem 
atenção demasiada, pois pode parecer que carregam um interesse além do que sua função representa na narrativa, sugerem a adição e a incorporação de propriedades ocultas (THOMPSON, 2004: 521). Contatos de $4^{\circ}$ Grau repete não só elementos, como a coruja branca exibida durante os diversos tratamentos de hipnose procedidos pela psiquiatra e também ao longo da narrativa (logo antes dos momentos de sono da personagem); existem ainda as repetições de algumas situações, mostradas por diferentes dispositivos de visualidades e em diferentes níveis de realismo, já que “a alegação de 'realismo' na pintura e na literatura é em grande parte devido a noção de que a visão é o guia mais confiável para o mundo como também é a que mais imediatamente nos afeta" (BROOKS, 2005: 03).

Apollo 18 faz um uso mais moderado da variedade de visualidades, mantendo-se fiel quase inteiramente à câmera de mão e às câmeras de vigilância dos módulos lunares. Quanto a Contatos de $4^{\circ} \mathrm{Grau}$ usam-se modalidades distintas de imagens realistas, visualidades que se complementam e se suplementam, ao mesmo tempo em que fragmentam as situações da narrativa. Em alguns momentos são acionadas simultaneamente dramatizações e reencenações, junto a testemunhos e entrevistas em voz over que corroboram as situações encenadas, além de imagens de arquivo registradas por câmeras de vigilância ou câmeras amadoras: todas essas modalidades relatam a mesma situação narrativa em uma dinâmica sinergética e redundante, algumas vezes inclusive reunindo todas em um mesmo plano por split screen.

Caracteriza um esforço de montagem em produzir um embasamento retórico a partir de visualidades fragmentadas e duplicadas, buscando compensar e realçar o excesso ficcional através de uma diversidade de modelos realistas, porque nesse sentido as "ficções devem mentir em ordem de dizer a verdade: elas devem escorçar, sumarizar, perspectivar, dar uma ilusão de completude a partir de fragmentos" (BROOKS, 2005: 06). As diversas fontes visuais e sonoras de uma mesma cena - dramatizações, imagens de arquivo, entrevistas e câmeras de vigilância apesar de desaceleram a cadência natural da narrativa, funcionam como testemunhos da legitimidade da trama.

Peter Brooks declara que a visão é insuspeita, digna de confiança e crença devido a sua objetividade e imparcialidade e "portanto qualquer consideração honesta sobre o real, no sentido das aparências do mundo, precisa recorrer a inspeção visual e inventário" (2005: 16). Quando o excesso ficcional se destaca, as narrativas conduzem seus respaldos também através de excessos, seja por meio de reiterações de documentos e informações, ou por meio da diversidade de representações sobre um mesmo fato: o excesso ficcional é distribuído por vários artifícios de visualidades realistas para exercer seus afetos adequadamente.

Todos os fragmentos documentais são convocados pela montagem em um regime de mostração visual de uma realidade extraordinária e excessiva, registrada exatamente por este 
atributo, algo que desestabiliza os limites da ficção - se o extraordinário deve ser registrado por um olhar realista, como o banal deveria ser registrado? Esse regime ainda é valorizado não só pelas fontes documentais, mas também pelo "agente documentador". Há um crivo do agente que documenta os fatos da ficção necessário para sua credibilidade?

Os modos como estes diferentes agentes documentais se posicionam nas tramas intensificam os argumentos hiperbólicos, pois os personagens são decorados com atributos de imparcialidade e respeito, já que registram os fatos com intuitos científicos e clínicos. São especialistas como astronautas e psiquiatras os responsáveis por narrar e também, em diversos momentos, registrar os fatos com os mecanismos audiovisuais - profissionais confiáveis para atestar a fidedignidade das suposições excessivas e capazes de operar o dispositivo que registra os fatos narrativos.

Outra característica interessante que se sobressai desse fator é o engajamento profissional que gradativamente se torna pessoal ao se documentar a razão oculta que as autoridades não querem revelar ${ }^{8}$. Nas tramas as personagens são envolvidas enquanto "agente documentador" primeiramente como profissionais realizando um procedimento de registro com fins científicos. Ao longo da narrativa, as personagens desenvolvem apegos íntimos sobre o registro, são tomadas de uma responsabilidade individual para com a verdade, levantando evidências, pistas e provas de suas próprias condições dentro do problema: a experiência científica torna-se autobiográfica.

Esta responsabilidade com a documentação do desconhecido é um compromisso quase altruísta, principalmente porque os protagonistas querem que outras pessoas sejam advertidas sobre os malefícios do mistério por meio de seus auto-relatos e auto-sacrifícios. Riegler declara que alguns filmes de horror acabam sugerindo que "a única esperança para a humanidade depende de virtudes como amor, auto-sacrifício e fé - reações culturais típicas para estados de incertezas" (2009: 113). Uma vítima cuja sistematização de sua auto-documentação poderá salvar pessoas destituídas do que a experiência pessoal lhe ensinou.

Mesmo em meio a tal responsabilidade os personagens estão fadados a obedecer o crivo dos dispositivos de visualidades, que oferece uma zona de indeterminação da imagem através de defeitos e interferências eletrônicas sofridas pela máquina que escondem a entidade monstruosa. Parece não suportar a representação ou a ação do monstro e sempre acaba sofrendo defeitos e interferências sobre sua captação. Enquanto dispositivo de registro do real, que nesse

\footnotetext{
${ }^{8}$ Um mistério possui duas instâncias opositoras, de um lado aquele que quer descobrir e revelar o que está oculto, de outro aquele que quer manter o mistério enquanto tal. Nos filmes analisados esta entidade mantenedora é associada a autoridades americanas: a polícia, a NASA, o FBI ou o serviço secreto são vistos como reguladores da razão oculta, agentes que procuram esconder, despistar e desmentir as hipóteses encorajadas pelas narrativas.
} 
caso presta-se a captar os excessos da realidade, sua função é rompida, sua lente se limita a visualizar apenas metáforas e metonímias de alteridade.

Em Contatos de $4^{\circ} \mathrm{Grau}$, os momentos em que as personagens são possuídas ou abduzidas pelas entidades extraterrenas não são inteiramente mostrados pelas câmeras (ou pela reencenação), contemplamos mais uma vez fragmentos, vertigens e rascunhos trepidantes completados apenas pelo que a imaginação consegue tatear. Imagens que em narrativas cinematográficas clássicas seriam eliminadas pela decupagem de edição, tornam-se a condução estilística que produz o engajamento sensorial e a crença narrativa - um horror provocado por imagens distorcidas, pelo choque perante a dúvida sensível que esta indeterminação emana.

Já os alienígenas de Apollo 18 são mostrados em raros momentos, mas a própria portabilidade abrupta capacitada pela câmera de mão atrapalha a configuração da imagem monstruosa, limitada ainda pela tecnologia, pois trata-se de uma câmera de $16 \mathrm{~mm}$ em um local de luz precária (o lado "escuro" da lua), onde os habitantes se mimetizam à única forma destacada em um deserto rochoso, as pedras. Dentro dos módulos, as imagens mantém-se estáticas e quase imutáveis, confinando a visão em um ambiente cada vez mais claustrofóbico.

Quando as câmeras de vigilância dos módulos lunares tomam os pontos de vista sobre a narrativa as imagens se tornam monocromáticas, mais amplas e lentas. Essa variação de dispositivos de registro apresenta ainda outro tipo de problema, pois os formatos das janelas de exibição são diferentes para cada equipamento - em termos técnicos o formato da $16 \mathrm{~mm}$ é de 1:1,33 com proporção de tela de $3 \times 4$, já a câmera de vigilância possui um formato de 1:2,35 com proporção de tela de $3 \times 7$. Esta variação em uma ficção clássica seria proibida, um problema de continuidade de formato que poderia deturpar a ilusão e a fruição fílmica.

No caso dos filmes aqui discutidos, essa variação não interrompe a crença narrativa, pelo contrário, tanto as interferências sobre a imagem em Contatos de $4^{\circ}$ Grau quanto os problemas de iluminação e de continuidade em Apollo 18 contribuem para o "efeito de real" conduzido pelas narrativas. Os defeitos parecem vincular as ficções à verdade por carregarem uma ruína, um registro deformado porém único sobre o fenômeno, e independente de sua falta de primor estético, seu defeito confere o valor de autenticidade que respalda a ficção. Laurent Jullier e Michel Marie (2009, p.66) defendem uma pequena tese sobre as peculiaridades dos defeitos serem proveitosas para filmes que desejam apego ao real, já que hoje a sofisticação técnica é ligada às imagens que servem para mentir, como o videoclipe espetaculoso e as imagens publicitárias hiper-realistas.

Há uma portabilidade permitida pelos dispositivos que determina o caráter testemunhal das imagens. Tanto a hand-cam digital da Dra. Tyler, quanto a $16 \mathrm{~mm}$ dos astronautas permitem um deslocamento imediato até o acontecimento, e embora não permitam 
visualizar o horror, conferem credibilidade à atualidade do registro. A portabilidade mesclada aos defeitos mantém certa coerência para com a proposta, pois tratando-se de tecnologias feitas para registrar o que pode ser representado, seria inconsistente à trama se pudessem registrar o extraordinário, aquilo que excede a natureza de sua função, algo que é não-conhecimento para o senso comum, é unicamente desconhecido - como representar o que não pode ser conhecido?

\section{Considerações finais: a retórica que veio de outro mundo}

E porque os antigos deuses haviam morrido por inúteis os homens descobriram outros que sempre tinham existido encobertos pela sua não necessidade.

José Saramago, O Ano de 1993.

Os filmes investigados imbricam modos de condução realistas e sensacionais para exercerem os efeitos do horror. São modos regidos por formas documentais, científicas e autobiográficas, associados a elementos, arquétipos e artifícios tipicamente ficcionais. Após o horror sanguinolento da exibição obscena de vísceras e corpos decompostos, surgiram filmes como estes, agora comuns na cinematografia mundial recente. Desde A Bruxa de Blair (1999) tais produções trouxeram um novo tipo de estética ao demonstrarem que a não visualização total do horror poderia ser mais afetiva se caracterizada realisticamente, uma "autenticidade implícita sobre a artificialidade perfeita; bem como os contextos envolvidos e as implicações circundantes do que nós pensamos sobre "horror"” (ALOI, 2005: 187).

A proliferação de imagens sobre a mesma situação em Contatos de $4^{\circ}$ Grau é um bom exemplo disso, porque o filme modula as imagens realistas através de artifícios da montagem aproximados aos da ficção - além do split screen e das dramatizações já citadas, no nível sonoro podemos ver a interferência de melodias e músicas na construção de uma atmosfera sombria, e também relatos em voz over; algo que Apollo 18 evita até os créditos finais, permanecendo com fontes sonoras diegéticas durante sua narrativa linear e cronológica.

Apesar disso, Contatos de $4^{\circ}$ Grau procura convocar um regime ético, como se quisesse alertar o espectador, denunciar o fenômeno terrível que abateu algumas pessoas em uma cidade remota do Alaska. Referenciar-se na própria história da suméria é uma maneira de reforçar os traços com a realidade: o diretor, agora também imbuído de conhecimentos especializados, declara que na arte suméria existem evidências e representações artesanais de foguetes e astronautas glorificados como deuses. A narrativa comenta a história cultural para formular retoricamente uma "arqueologia da abdução" - um conhecimento erudito sobre as religiões e culturas antigas empenhado em legitimar os excessos ficcionais. 
Da maneira semelhante Apollo 18 ramifica sua lógica em arquivos hiper-textuais aproveitando-se da carência de expertise do receptor. Instruídos com um conhecimento limitado sobre um universo infinito, somos embasados praticamente nos argumentos teóricoespetaculosos filtrados e diluídos pela mídia. O filme ancora-se nessa imaginação de nãoconhecimentos para resguardar suas noções cosmo-conspiratórias que "tratam de estruturas que estão e estarão, talvez para sempre, no domínio da imaginação, do ultra-sensível, dentro de um programa teórico fora do nosso controle observacional" (NOVELLO; FREITAS, 1996: 495).

As visualidades buscam um estatuto realista pois já não há o que ser estilizado ou ressaltado, o incógnito é excessivo por natureza: enquanto não-conhecimento possui forma indeterminada, mas não negativa, este não-conhecimento não é nada, é alguma coisa, embora não se saiba exatamente o que é e por isso permite que a imaginação estipule qualquer parâmetro ou representação para compensar seu ocultismo, um excesso de possibilidades que se expande ao passo que novas assunções possam ser formuladas. Mistérios e visualidades realistas completam-se nas narrativas, compõem os fios que atravessam a experiência fílmica costurando os estímulos cognitivos aos sensacionais.

Podemos dizer que a imaginação sentimental do desconhecido é o campo da criação e da fabulação, da compensação em absentia, organização imaginativa de um sentido lógico para o que não se conhece. Aludir como lógico ao que não-se-conhece é um exercício de exceder não só os conhecimentos, mas também os sentimentos que se concebem na realidade. Nesse sentido, podemos dizer que alguns filmes de horror contemporâneos, como os debatidos aqui, não mostram tudo, mas deixam ver mais do que os olhos conseguem enxergar.

\section{Referências bibliográficas}

ALOI, Peg. "Beyond the Blair Witch: a new horror aesthetic?" In: KING, Geoff (Ed.). The spetacle of the real: from Hollywood to reality TV and beyond. Bristol/Portland: Intellect Books, 2005, p.187-200.

AUMONT, Jacques; MARIE, Michel. Dicionário teórico e crítico de cinema. 2.ed. Campinas, SP: Papirus, 2006.

BROOKS, Peter. Realist Vision. New Haven/London: Yale UP, 2005.

The melodramatic imagination: Balzac, Henry James, melodrama and the mode of excess. New Haven/London: Yale UP, 1995. 
DIDI-HUBERMAN, Georges. "Image-archive, image-apparence". In: Images Malgré Tout. Paris: Minuit, 2003, p. 115-150.

JOURNOT, Marie-Thérèse. Vocabulário de Cinema. Lisboa: Edições 70, 2005.

JULLIER, Laurent; MARIE, Michel. Lendo as Imagens do Cinema. São Paulo: Senac, 2009.

NOVAES, Adauto. "Políticas do Medo". In: (Org.). Ensaios sobre o Medo. São Paulo: Senac/Sesc, 2007, p.9-16.

NOVELLO, Mário; FREITAS, Luciane R. de. "Crítica da razão cósmica". In: NOVAES, Adauto (Org.). A Crise da Razão. São Paulo, Brasília e Rio de Janeiro: Cia. Das Letras, Ministério da Cultura e Fundação Nacional de Arte, 1996, p.495-506.

PÉCORA, Alcir. "Razões do Mistério". In: NOVAES, Adauto (Org.). A Crise da Razão. São Paulo, Brasília e Rio de Janeiro: Cia. Das Letras, Ministério da Cultura e Fundação Nacional de Arte, 1996, p.157-172.

POLAN, Dana. "Eros and Syphilization. The contemporary horror film". In: GIBIAN, P. (org). Mass Culture and everyday life. NY and London: Routledge, 1997.

RANCIÈRE, Jacques. "Do Medo ao Terror". In: NOVAES, Adauto (Org.). Ensaios sobre o Medo. São Paulo: Ed. Senac São Paulo / Edições Sesc SP, 2007, pp. 53-71.

RIEGLER, Thomas. "Fear, Horror, Terror: Violent Movies for Violent Times". In: HILL, Shona; SMITH, Shilinka. There Be Dragons Out There: Confronting Fear, Horror and Terror. Oxford: Oxford I-D Press, 2009.

THOMPSON, Kristin. "The concept of cinematic excess". In: BAUDRY, Leo; COHEN, Marshall (Orgs.). Film Theory and Criticism. NY and Oxford: Oxford University Press, 2004, p.513-524.

Fontes Primárias

Albergue, O (Hostel). ROTH, Eli. USA. 94 min. 2005.

Alien. SCOTT, Ridley. USA/UK. 117 min. 1979.

Apollo 18. LÓPES-GALLEGO, Gonzalo. USA/CAN. 86 min. 2011.

Bruxa de Blair, A (The Blair Witch Project). MYRICK, Daniel; SÁNCHEZ, Eduardo. USA. 81 min. 1999.

Contatos de $4^{\circ}$ Grau (The Fourth Kind). OSUNSANMI, Olatunde. USA/UK. 98 min. 2009. Jogos Mortais (Saw). WAN, James. USA/Austrália. 103 min. 2004. 
L'Arrivée dun train à la Ciotat. LUMIÈRE, August; LUMIÈRE, Louis. FRAN. 1 min. 1896.

Viagem à Lua (Le voyage dans la lune). MÉLIÈS, Georges. FRAN. 14 min. 1902.

2001-Uma Odisseia no Espaço (2001: a space odyssey). KUBRICK, Stanley. USA/UK. 141 min. 1968. 